\title{
WHO IS THE BEST? INSIGHTS FROM THE BENCHMARKING OF BORDER REGIONS
}

\author{
Daniela Grozea-Helmenstein $^{1}$, Christian Helmenstein ${ }^{2}$, and Tatiana Slavova ${ }^{1}$ \\ ${ }^{I}$ IHS Institute for Advanced Studies, Vienna, and ${ }^{2}$ ECONOMICA Institute of \\ Economic Research and IV Federation of Austrian Industries, Vienna
}

\begin{abstract}
This paper analyzes the attractiveness of 61 NUTS-2 EU regions as FDI locations, with an emphasis on the Austrian regions and the border regions in the neighbouring countries. To this end, the paper proposes a novel benchmarking methodology, which is based on the solution of a non-linear and non-convex optimisation problem and allows for the simultaneous evaluation of all indicators. Based on identical vectors of indicator weights for all regions under scrutiny in two cases and on region-specific vectors in a third case, we construct three different indices of location attractiveness. These differ from each other in terms of the underlying notion of optimality. Intervention-induced rank-engineering is ruled out since all indicator weights are determined endogenously jointly with the algorithmic solution to the optimisation problem. The empirical analysis conducted hereafter, drawing upon output-oriented indicators, demonstrates the applicability of the methodology.
\end{abstract}

DOI: $10.3176 /$ tr.2009.3.06

Keywords: regional economics, efficiency analysis, benchmarking, foreign direct investment, location attractiveness

\section{Introduction}

International competition for foreign direct investment was perceived for decades as a challenge to be mainly addressed in a nation-wide manner. At the macroeconomic level, national policy aimed at creating an attractive framework with regard to the horizontal division of labour. As to this matter, during the past few years the focus has been on tax policies and particularly on business taxation and the (direct and indirect) funding of research. By contrast, at the microeconomic level investment promotion agencies competed to attract foreign direct investment through a variety of services comprising, inter alia, location marketing, 
the provision of incubator and cluster structures, access to subsidies, and expatriate settlement coaching. Location quality plays a major role in directing foreign direct investment. The term refers to the extent at which the performance-related requirement profile of enterprises, the location-related framework conditions, and the production factor-specific endowment at destination can be expected to match each other.

In recent years, the quest for an improvement in location-specific conditions for production and/or the performance of headquarters functions, intersected with a more focused approach to attract potential investors, involved regional political actors to a greater extent than before as well. Regions do no longer delegate the acquisition of foreign direct investment to the national level but get themselves engaged in the related tasks with region-specific institutions and instruments (for example in the form of an autonomous regional brand management). In effect, the conventional horizontal division of labour is supplemented by a vertical division of labour between different political authority levels. The fact that the relevant market is shaped less according to national but more according to regional boundaries implies a second level of interregional competition.

Regions are therefore striving to adapt to constantly changing conditions in order to at least maintain their competitiveness and, if possible, even to increase it. When analyzing their competitiveness, they see themselves, however, confronted with a large number of variables that are to be considered, coupled with the difficulty to set the selected variables in relation to each other. In particular, tradeoff relationships among variables - an improvement of one parameter can sometimes be carried out only at the expense of one or more other parameters - as well as problems of multicollinearity should be taken into account. These issues were only irrelevant if a region had a dominant competitive position with regard to all variables, which will very rarely be the case.

There is a plethora of rankings available concerning the quality of investment locations on the one hand, and catalogues of presumably important investment drivers on the other. On the basis of such compilations to date quite frequently farreaching conclusions are drawn concerning the location-specific chances of success in the international competition for foreign direct investment. The paper presents a literature overview on various methodologies used for regional benchmarking and discusses some of their shortcomings. Then it introduces the newly developed models for regional benchmarking purposes and presents the selection of indicators to be used in the empirical application of the models. Finally it concludes with policy recommendations.

The purpose of this paper is to identify the relative strengths and weaknesses of regions in the sub-national competition for foreign direct investment in a consistent manner. To this end, we apply a new method for the (retrospective) benchmarking of regions in terms of their location quality and competitiveness in an international framework. We present three different benchmarking indices, namely BEOW (Border-oriented Equal Optimal Weights), EEOW (Envelope-oriented Equal Optimal Weights), and SOW (Specific Optimal Weights), which have been 
constructed to assess the location quality of a sample of altogether 61 NUTS-2 European regions. More concretely, the portfolio of regions under investigation relates to Austria (9 regions), the Czech Republic (8), Germany (13), Hungary (7), Italy (19), the Slovak Republic (4), and Slovenia. Because of the relative smallness of the latter country, the national and the regional scope coincide. On the basis of these indices we analyze the attractiveness of the regions as location for foreign direct investment. The focus of the analysis is on the nine Austrian federal states, which are all border regions, and their counterparts, the border regions Jihozápad and Jihovýchod in the Czech Republic, Bratislavský Kraj and Západné Slovensko in the Slovak Republic, the two Italian regions Veneto and Friuli-Venezia-Giulia, the region Nyugat-Dunántúl from Hungary, and Slovenia.

\section{Benchmarking: literature overview}

There is a broad consensus that foreign direct investment confers a net advantage to national and regional economies, with the exception that under rare and extreme policy regimes this finding may turn out to be reverse (Mullen and Williams 2005). FDI causes an influx of capital, yields additional jobs that are usually better remunerated as those available locally beforehand, fosters the diffusion of new technologies, and thus enhances welfare in the recipient economies.

In order to reap these immediate potential gains and, additionally, to benefit from positive externalities, regional policy makers are willing to enter a fierce competition by offering potential investors from abroad both facilities and subsidies with the aim of attracting new production plants to their locations (Parcero 2004). Multinational corporations (MNCs) are regularly considering different regions from within a country as well as from different countries simultaneously in order to identify the location with the most beneficial conditions.

While the exact terms of such investment deals are usually kept non-public, there is substantial anecdotal evidence of this kind of subsidy-related competition. To illustrate, in 1993 the state of Indiana offered a package worth USD 300 million to attract a United Airlines maintenance facility that was expected to create 6,300 jobs. Kentucky provided USD 140 million in the form of tax credits to attract 400 steel jobs. Also on the municipal level, intergovernmental competition is quite common in order to attract plants (King, McAfee, and Welling 1993).

The academic literature has not been silent on the competition for foreign direct investment (FDI) either. King and Welling (1992) and King, McAfee, and Welling (1993) provide a model with two periods and two regions and analyze the efficiency of regional competition, under the assumptions that regional public authorities promise or not tax advantages to the investing company.

Barros and Cabral (2000) analyze 'subsidy games' between two potential destination countries in order to attract foreign direct investment (FDI) from a third country of origin. Adams and Regibeau (1998) and Parcero (2004) explore government intervention in the competition for FDI. The authors perform welfare 
comparisons between the equilibrium achieved by competitive subsidy, zero subsidy, and first-best subsidy.

In order to prevail in the competition for foreign direct investment, governments on the sub-national level hope to marshal arguments in favour of their location from inter-regional comparisons of location attractiveness, whereas investors draw upon these in order to compute minimum offset requirements on a factor-specific basis or from a portfolio point of view.

\section{Shortcomings of current benchmarking methodologies}

The rankings of countries, regions, or cities experience considerable resonance in the media and in different areas of policy-making. In order to achieve maximum audience, the originators of these evaluations tend to focus on 'winners' and 'losers', in addition to the absolute placement of a territorial unit in international competition. In the concerned regions/cities such rankings meet different reactions. While the 'best'-placed regions usually accept the results without any criticism concerning the methodology and incorporate them in their marketing activities, regions, which are not ranked among the best frequently commission studies that do not only doubt the methodological approach used but at times generate (diametrically) different results as well.

For regional governments it is usually quite easy to disapprove of the results of conventional rankings as these show major methodological weaknesses (see Schönert 2003, Grozea Helmenstein et al. 2005). Sometimes the discussion evolves in the spirit of a 'beauty contest' (almost) exclusively around the placement in the overall ranking, while long-term development strategies are not showing up in short-term improvements in the placement. Regional stereotypes consolidate themselves ('recursive self-affirmation') as long as the results of rankings appear to confirm a priori suppositions. If survey results are linked to the exercise, the ranking reflects perceptions (as well), which may not necessarily be in accordance with the underlying facts. In addition, there are a number of methodological problems. Therefore, the results of some rankings should be interpreted with great caution, or even discarded. Among these problems are the availability of appropriate and recent indicators, their teleologically consistent relationship to the analysis, the comparability of indicators across different territorial units, and the selection of the entities to be benchmarked.

Most regional data are published with a time lag of two to three years. The positioning of individual regions, especially of those in the midst of a process of profound economic restructuring (for instance the regions of the new EU member states) can be substantially different when using more recent data. Depending on the choice of indicators, rankings can ceteris paribus substantially diverge from each other. A rank order, which is primarily based on income-related output variables will typically differ significantly from rankings based on employmentrelated output variables. Many rankings include both input and output variables in 
a logically unconnected way. This leads to a blending of elements of evaluation with those of control, with the result that the rankings are useless for evaluation or policy design purposes. The use of regional definitions for individual indicators makes them unfeasible for interregional analyses; distortions can possibly be avoided by using the rates of change instead of data in levels, where appropriate. The choice of the other benchmarking entities in terms of their number and their relevance is not only important for the relative placement in a ranking order but even more so for the absolute placement. For instance, a tenth rank in a given year may represent a better placement than a fifth rank in the previous if the number of regions under investigation has been greatly expanded. This would apply a fortiori if the leading peer regions from the previous year would be placed after the considered region in the most recent ranking. Other weaknesses according to Peneder (1999) are: a synthetic index formula is of very limited use if it extremely simplifies complex relationships; an insufficient provision for country-specific comparative trade advantages and production structures, which makes rankings less relevant. In addition, in some cases the heterogeneous selection of indicators ranging from labour market variables to indicators of environmental quality or the recreational attractiveness of a region - may indicate a lack of theoretical foundation.

Common rankings, inasmuch as they are index-based and are not merely a collection of figures, are often dependent on a priori defined weights (Huggins 2003). To construct such indices, usually experts are consulted to assign specific weights to the indicators used. In individual cases there may sometimes be a good reason behind this practice, such weights reflect subjective assessments, however. Worse, the assigned weights may be the result of an isolated view on individual indicators, while the possibly complex interaction between them is left unaccounted for. For a consistent comparison of regional location attractiveness, however, the incorporation of the latter would be a must.

Altogether, such kind of an approach renders benchmarking largely useless, as in general there is no triggering of an insight-driven political process, which would be necessary to maintain and improve regional attractiveness. Regional benchmarking exercises may thus not seem effective and may therefore be questioned as a matter of principle. In the best case the conceptual weaknesses of conventional approaches affect the usefulness of the results for economic policy design, in the worst case they may cause grave mistakes in regional positioning and thus constitute a waste of resources.

Our approach to calculate indices of location attractiveness has been inspired by preparatory work of the British Department of Trade and Industry that carried out an estimate of regional economic development in the form of a balance sheet of available statistical information (Department of Trade and Industry 2001). This so-called DTI index includes enterprise creation and survival rates, employment, value added per employee by industry, the average income, and GDP per capita. In addition, a number of other indicators were taken into consideration, including spending on education and infrastructure. 
Another relevant contribution is the 'Knowledge Based Economy Index', which derives from the former 'New Economy Index' of the Milken Institute. This index measures the regional economic performance in the United States based on high tech-related indicators (De Vol 1999). The 'Metropolitan New Economy Index' of Atkinson and Gottlieb (2001) also uses exogenously given weights. In the composite analyses, the indicators were weighted so that closely correlated ones would not bias the results. The Global Competitiveness Report of the World Economic Forum (2004) uses both quantitative and qualitative indicators and classifies them in eight groups, as follows (weights in brackets): openness (1/6), government (1/6), finance (1/6), infrastructure (1/9), technology (1/9), administration (1/18), labour market (1/6) and institutions (1/18). The innovation index of Porter and Stern (1999) uses a number of patent-related variables to assess the 'innovation stage' of a country. However, many indicators are highly correlated with each other. If this correlation structure is not taken into account, exogenously determined weights imply the overrepresentation of certain location characteristics (Huggins and Izushi 1999).

\section{Model development}

In order to overcome the shortcomings as elaborated above and to create reasonable results, we propose a new methodology to calculate indices of location attractiveness. This approach draws upon the notion that findings, which have been deduced using a transparent set of rules that was known and unanimously agreed upon a priori should be accepted by all stakeholders involved, independent of whether the concrete individual results are welcome or not.

A promising candidate to assess the attractiveness of a region consists in an application of Data Envelopment Analysis (DEA) and Stochastic Frontier Methods (SFM; Greene 2003). Herrera at al. (2005) used DEA and the Free Disposable Hull (FDH) to evaluate the efficiency of the health and education systems in 140 developing countries. In contrast to DEA the FDH assumes free disposability of resources. In addition to DEA, Afonso et al. (2005) used the semiparametric DEA/Tobit two-step procedure. DEA was also applied by Todd et al. (2007) to assess the relative efficiency and flexibility of public spending on health care, education, and social protection in Slovenia compared to the old and new EU member states. Kempkes et al. (2007) applied DEA to analyze the efficiency of 72 public German universities for the years 1998 and 2003. Also the United Nations, the European Commission, OECD, and other international organizations have developed multi-criteria indices and use them in different fields of evaluation.

Althaler and Slavova (2000) provide an overview of these methods, also taking account of geometric or stochastic uncertainty of data. The data are either known to be in a polytope or to conform to a predetermined probability distribution. The proposed DEA approaches to solve the geometric uncertainty of data draw upon 
methods of linear programming or of the minimax optimization approach, while the stochastic data uncertainty can be countered by implementing SFM optimization methods.

For the following models we assume that each region is characterized by a set of variables. Hence the data can best be represented in the form of a matrix. The data were normalized and positively oriented, which means that the regional attractiveness is increasing in the value of a given variable. For the normalization of data we used various approaches:

1. Standard deviation from the mean (current value - mean) / standard deviation.

2. The distance in percent to the best characteristics $100 *$ (current value / maximum value).

3. Distance in percent from average $100 *$ (current value / mean).

4. Distance from the specific best to the specific worst region (as a benchmark for the positioning of a region in relation to the global maximum and minimum) $; 100 *$ ((current value - minimum value) / (maximum value minimum value)).

Following these preparatory operations, we now proceed with an application of an extended DEA to gauge regional attractiveness. The three models presented below differ from each other according to the underlying notion of optimality with regard to the weighting schemes applied.

\subsection{BEOW model}

The BEOW (Border-oriented Equal Optimal Weights) index is based on the optimality concept that the result of a benchmarking may be considered as fair if the aggregate deviation of all regions from the best result is as small as possible. On the contrary, a weighting scheme that appears to arbitrarily assign high weights to some specific location factors and low weights to others may be interpreted as dominated by individual weighting preferences and is thus not acceptable as an objective weighting scale. The optimization calculus used herein is therefore based on the endowment of all regions with location factors and their specific characteristics. As a result, those regions will be above (below) an average position, which achieve the relatively best (worst) positions in the dominant variables with regard to the totality of all regions. The weights are identically chosen for each region such that the ranking is based on a composite index in relation to the maximum value.

\subsection{EEOW model}

In the case of the EEOW (Envelope-oriented Equal Optimal Weights) index the optimality concept described above will be modified as follows. In the present case we will no longer consider the difference to the singular best result but rather the deviation of the results from an efficiency envelope will be minimized by using an optimization calculus. This weighting scheme takes into account, unlike the previous one, trade-off relationships between various location factors. 
Thus, empirically existent structural restrictions in the endowment with location factors are also taken into account. This model was also used in the work of Beyko et al. (2005).

\subsection{SOW model}

The Specific Optimal Weights (SOW) model represents a multi-extreme optimization problem. Unlike the other two models, it is based on region-specific weights. This index can be seen as a DEA (Data Envelopment Analysis) extension. As with DEA, the efficiency of a region is considered in relation to the other regions (Althaler and Slavova 2000). For each region the weights are selected in such a way that the considered region is located as close as possible to the efficiency border and the composite index reaches the maximum value in relation to the individual indexes of all other regions with the same weight combinations. The index reflects an optimality calculus based on the heterogeneity of regions. It provides an answer to the question whether a region with one or more specific combinations of factors can accomplish a position on the efficiency frontier.

\section{Empirical analysis}

\subsection{FDI determinants}

Any firm that is active abroad has to carry extra costs. These extra costs are comprised of transport costs, (from language and other cultural barriers arising) communication costs, market exploitation costs, and risk premia. In the absence of offsetting factors such as access to superior technology compared to that used by the competition or cost advantages due to economies of scale and other group advantages it would be preferable not to pursue an investment project abroad (Felderer et al. 2000).

Following Dunning (1979) there must co-exist three sets of determining conditions, which are known in the literature as the OLI Framework (Ownership, Location and Internalization) in order for a firm to engage in foreign direct investment:

- under ownership advantage are to be understood the advantages arising from the control over superior production factors (including patents and reputation capital);

- the location advantage refers to the advantages of foreign operating locations in relation to domestic operating locations (location advantage);

- however, the aforementioned advantages represent necessary but not sufficient conditions for an investment abroad. A firm could benefit from these advantages also through licensing agreements. Only if a firm expects to gain additional benefits from internalizing decision and conversion processes, that is, to reap an internalization advantage, foreign direct investment will ensue. Contrary to the ownership and the internalization advantage, which are firmspecific, location advantages are external to the firm. They can usually be 
created or influenced by appropriate economic policy, such as macroeconomic and regional economic policies.

Among the plethora of hypotheses aiming to explain the pattern of foreign direct investment, according to the classical theory of comparative advantage relative factor endowments and initial conditions are important factors in attracting FDI to some locations rather than others (Kravis and Lipsey 1982, Bhagwati 1987, Veugelers 1991). This implies that a specific location can influence investors' investment decision by changing its economic fundamentals (Resmini 2007).

Empirical studies undertaken in developing and developed countries show a positive correlation between FDI and a firm's productivity. They also evidence that multinational companies usually pay higher wages than domestic ones. Aizenman and Spiegel (2002) demonstrate that this phenomenon can partially be explained by the necessity for foreign-owned firms to use efficiency wages in an environment characterized by poor contract enforcement and high monitoring costs.

If a wage differential provokes a relocation of labour intensive productions to countries or regions where the wage level is lower than in the home country, FDI leads to a specialization in skill-intensive economic activity and in an increasing demand for high-skilled labour force in the home countries and a declining demand for low-skilled labour force. This will negatively impact on the employment and/or the wage level of low-skilled labour force but at the same time foster the international competitiveness of the (remaining) domestic production chain in the country of origin (Ekholm 2004).

The new trade theory explains FDI as a trade-off between trade costs and economies of scale (Markusen 1984, Helpman 1984). Traditional and new location theories underline the importance of trade integration and agglomeration effects as main drivers of FDI (Markusen and Venables 1995, Baldwin and Ottaviano 1997). Other authors like Wei (2000) and Antras and Helpman (2004) emphasize the importance of well-functioning institutions, especially in emerging markets, as a determinant of FDI.

The extent to which these location characteristics influence FDI decisions depends on project-specific investment characteristics and objectives. Three major objectives can be distinguished: Investments are 'market seeking' when they are motivated by the endeavour to gain better access to a market in terms of market size and/or per capita income (horizontal FDI). In this context, the proximity to the target location is a determinant of investment patterns, hence the term 'gravity' factor to denote the force that shapes the investment pattern (Shatz and Venables 2000). Investments are 'efficiency seeking' when the unit labour costs in the host countries are lower than in the home country (vertical FDI). In this case, prior to decision, foreign investors consider the prices of the factors of production (adjusted for productivity differences) and the membership of the destination country in regional integration agreements (UNCTAD 1998). Investments are 'resource-asset seeking' if the focus is on the availability of specific raw materials and the corresponding physical infrastructure (transportation, power, and tele- 
communication). Sector-specific incentives and restrictions may shape the pattern of foreign direct investment in a specific way.

\subsection{Selection of indicators}

For the empirical application of our models we have used as the main source of data the European Statistical Office (EUROSTAT 2005). This ensures that the indicators used to map the national and regional business environment and factor endowments are based on uniform definitions, thus rendering interregional comparisons feasible. All indicators chosen are output-oriented indicators. The data can be assigned to three indicator categories, more specifically: demographic data, economic data, and living conditions-related data. In addition to all Austrian federal states (border regions), we also include 52 NUTS-2 regions in Germany (13 regions), Italy (19 provinces), Slovakia (4 regions), Czech Republic (8 regions), and Hungary (7 regions), some of these regions being also border regions. The set of variables can be split up in yet another way: the first set of variables contains a total of thirteen individual indicators, which are available for each of the 61 NUTS-2 regions involved in the investigation (the so-called regional factors). The second set is comprised of four other complementary indicators, for which either general national regulation is in place and which therefore consistently characterize all NUTS-2 regions of a country, or for which only national averages are available although regional distinctions would essentially be possible (so-called aggregated factors). The variables considered are:

I Demographics:

- Average regional fertility rate 2000-2002;

- Regional differences in the elderly dependency ratio $(65+/(15-64))$.

II Economic data:

- Development of employment (\%), 2003-2002;

- Commuters share of the total employees of a region (residence principle);

- Unemployment rate (\%);

- Long-term unemployed (12 months or more) at NUTS-2 level - EU-25;

- Early school leavers (according to ISCED 0-3);

- Gross domestic product (GDP) per capita, PPP;

- Change in GDP per capita, PPP, \%;

- Disposable income of private households per capita in PPCS;

- Development of income and property taxes in percentage points of disposable income of households;

- Productivity (GDP per worker);

- High-tech exports (percentage of total exports);

- Budget expenditures on pensions (\% of GDP).

III. Living conditions:

- Hospital beds per 100,000 inhabitants;

- Doctors / physicians per 100,000 inhabitants;

- Public sector's investment in environmental protection (\% of GDP). 


\section{Location attractiveness}

\subsection{Results of the BEOW model}

The BEOW model draws upon uniform weights for various indicators. The factors identified by the model as significant for a foreign investment decision are:

-6 regional factors and

- 1 aggregated factor (see Table 1).

Table 1. Weights of indicators in the BEOW index

\begin{tabular}{lcc}
\hline Variable & Category & Weights \\
\hline Fertility rate & $\mathrm{R}$ & 0.1429 \\
Disposable income of private households & $\mathrm{R}$ & 0.1429 \\
Development of income tax and tax on assets & $\mathrm{R}$ & 0.1429 \\
Development of employment & $\mathrm{R}$ & 0.1429 \\
Share of commuters in total employment & $\mathrm{R}$ & 0.1429 \\
Old age dependency ratio & $\mathrm{R}$ & 0.1429 \\
Budget expenditures on pensions & $\mathrm{A}$ & 0.1429 \\
\hline
\end{tabular}

$\mathrm{R}=$ regional variables (defined at a NUTS-2 level)

$\mathrm{A}=$ aggregated variables (defined at country level)

The top-10 ranks regions according to this procedure are presented in Figure 1.

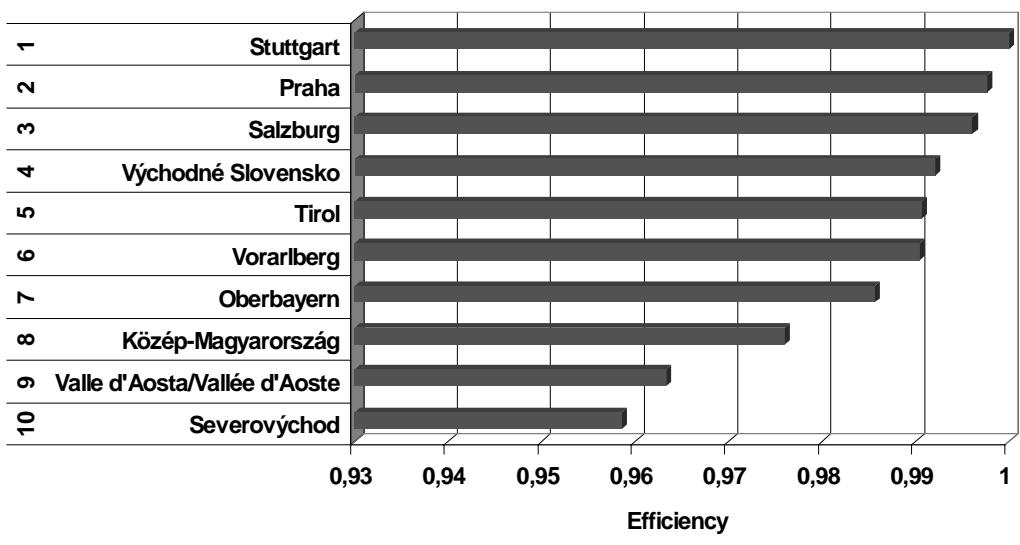

Figure 1. Regional attractiveness according to the BEOW model: top-10 regions.

We get two German NUTS-2 regions - Stuttgart (1st place) and Upper Bavaria (7th place), two Czech NUTS-2 regions - Praha (2nd place) and Severovýchod (10th place), 3 Austrian regions - Salzburg (3rd place), Tirol (5th place), and Vorarlberg (6th place), one Slovak region - Východné Slovensko (4th place), one Hungarian region - Közép-Magyarország (8th place), and one Italian region Valle d'Aosta / Vallée d'Aoste (9th place). 
Among the 61 NUTS-2 regions, the other Austrian regions Oberösterreich (19), Wien (28), and Kärnten (35), rank in the middle while Steiermark (40), Niederösterreich (50), and Burgenland (59) are located in the lower third of this series. Bratislavský kraj (11), Slovenia (13), and the Czech regions bordering Austria, Jihozápad (12) and Jihovýchod (16), rank in the top third. The Hungarian region Nyugat-Dunántúl is on rank 32, and the Slovak region Západné Slovensko on rank 45 (see Figure 2).

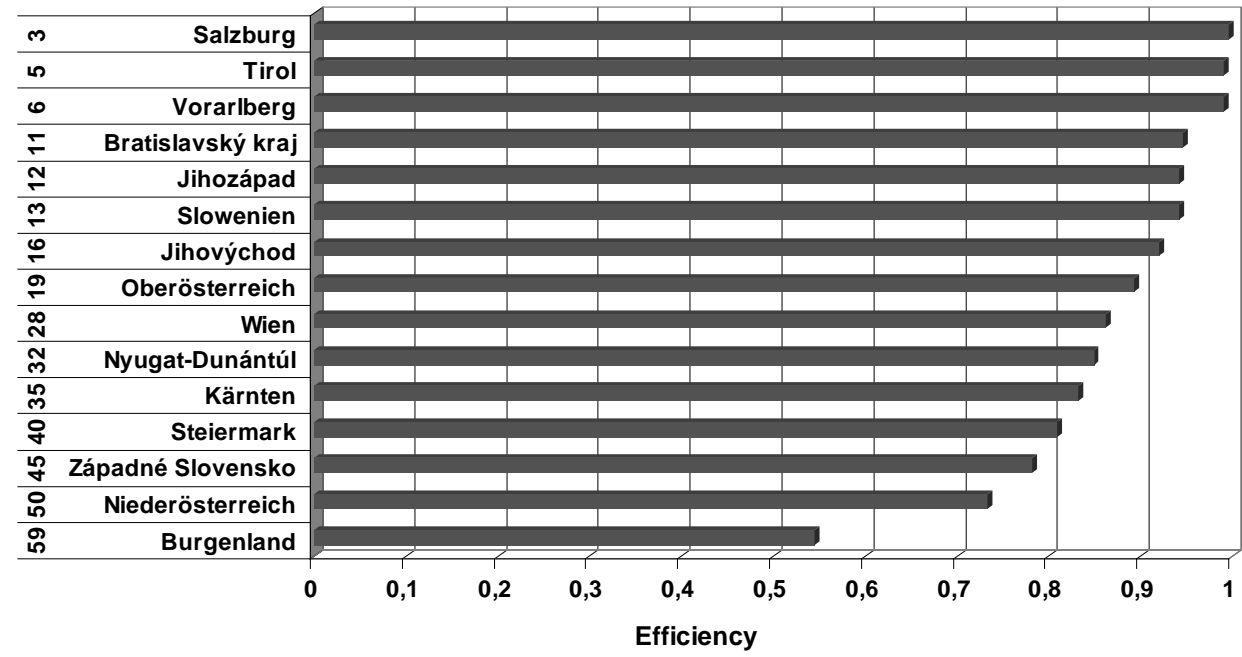

Figure 2. BEOW model: position of Austrian and neighbouring regions.

\subsection{Results of the EEOW model}

In the context of the EEOW model six regional factors and two aggregated factors were identified as significant, see Table 2:

Table 2. Weights of indicators in the EEOW index

\begin{tabular}{lcc}
\hline Variable & Category & Weights \\
\hline Fertility rate & $\mathrm{R}$ & $0.3536^{2}$ \\
Elderly dependency ratio & $\mathrm{R}$ & $0.3536^{2}$ \\
Disposable income of private households & $\mathrm{R}$ & $0.3536^{2}$ \\
Development of employment & $\mathrm{R}$ & $0.3536^{2}$ \\
Early school leavers & $\mathrm{A}$ & $0.3536^{2}$ \\
Physicians per 100,000 inhabitants & $\mathrm{R}$ & $0.3536^{2}$ \\
Productivity & $\mathrm{R}$ & $0.3536^{2}$ \\
Budget expenditures on pensions & $\mathrm{A}$ & $0.3536^{2}$ \\
\hline
\end{tabular}

$\mathrm{R}=$ regional variables (defined at the NUTS-2 level),

$\mathrm{A}=$ aggregated variables (defined at country level)

The top 10 regions according to the EEOW model are presented in Figure 3: 


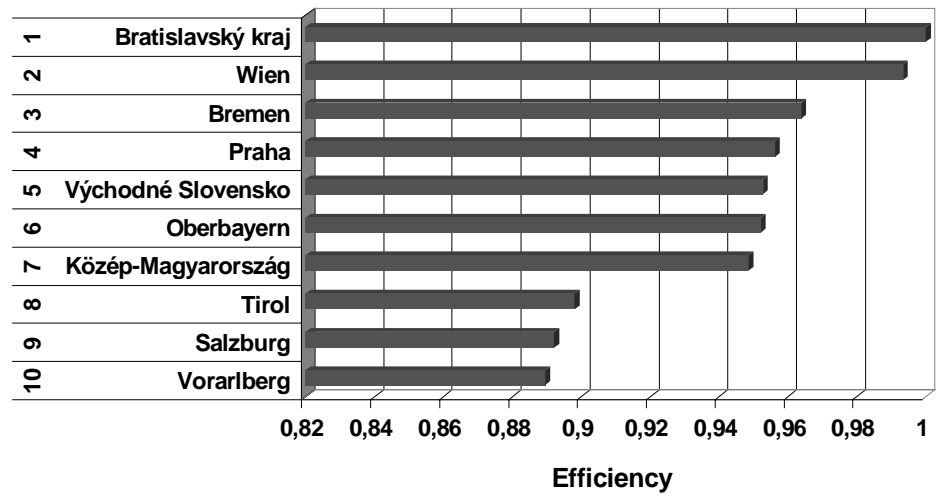

Figure 3. Regional attractiveness according to the EEOW model: Top-10 regions.

Two German NUTS-2 regions - Bremen (3rd place) and Upper Bavaria (7th place), one Czech NUTS-2 region - Praha (4th place), four Austrian regions Wien ( 2nd place), Salzburg (9th place), Tirol (8th place), and Vorarlberg (10th place), two Slovak regions - Bratislavský kraj (1st place) and Východné Slovensko (5th place), and one Hungarian region - Közép-Magyarország (7th place) constitute the top-ten ranks, with Bratislavský kraj on the very top position.

Among the 61 NUTS-2 regions, Wien (2nd place), Tirol (8th place), Salzburg (9th place), Vorarlberg (10th place), and Oberösterreich (18 place) are ranked among the first 20 regions; Niederösterreich (30th place) and Steiermark (35th place) together with the Slovak region of Západné Slovensko (22th place) and the Czech regions Jihozápad (36th place) and Jihovýchod (31th place) occupy middle places, while Kärnten (52th place) and Burgenland (49th place) are located in the lower third of this ranking. Slovenia and the Hungarian region Nyugat-Dunántúl are positioned on places 46 and 58 (see Figure 4).

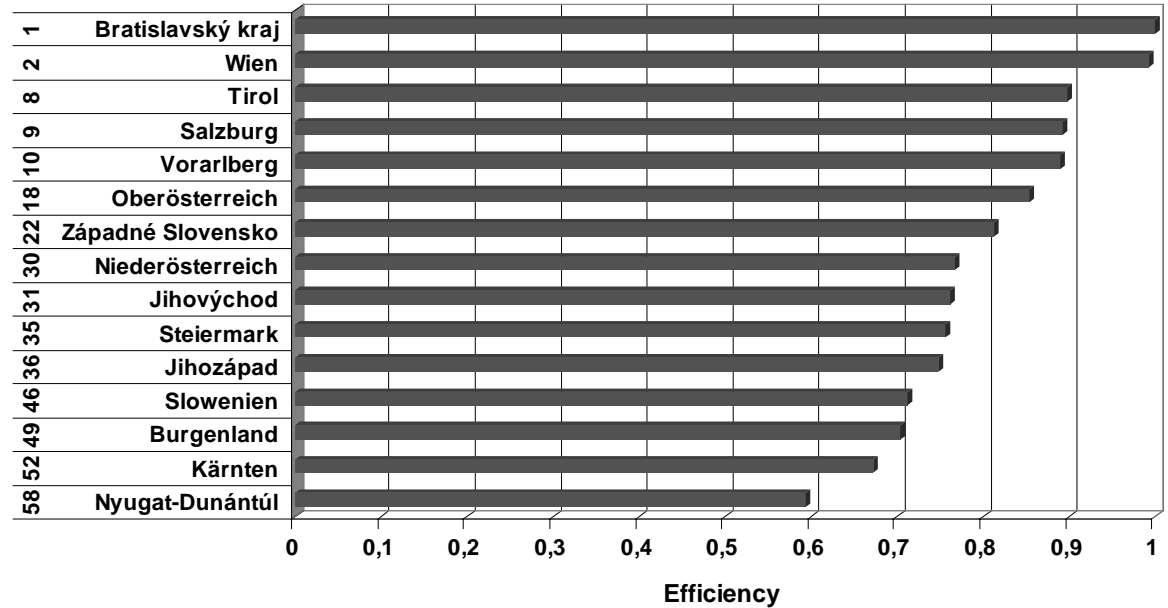

Figure 4. EEOW Model: Position of Austrian and Neighboring Regions 


\subsection{Results of the SOW model}

The model of specific optimal weights (SOW) is based on region-specific weights. These are chosen for each region in such a way as to minimize the distance of the specific region from the efficiency frontier. In effect, the composite index reaches its maximum (as a result of the division of the index value of the region by the maximum index value of all regions).

The maximum efficiency is achieved with the SOW model and the use of favourable indicator combinations by the following 35 NUTS-2 regions: Burgenland, Kärnten, Oberösterreich, Salzburg, Tirol, Vorarlberg, Wien, Praha, Severovýchod, Severozápad, Strední Cechy, Bremen, Stuttgart, Tübingen, Upper Bavaria, Dél-Alföld, Dél-Dunántúl, Észak-Magyarország, Észak-Alföld, Közép-Dunántúl, Közép-Magyarország, Nyugat-Dunántúl, Campania, Emilia-Romagna, Lazio, Liguria, Lombardy, Piemonte, Provincia Autonoma Bolzano-Bolzano, Valle d'Aosta / Vallée d'Aoste, Slovenia, Bratislavský kraj, Stredné Slovensko, Východné Slovensko, and Západné Slovensko. For the other NUTS-2 regions, the efficiency value is smaller than 1, including: Jihozápad (0.9897), Jihovýchod (0.9730), Niederösterreich (0.9729) and Steiermark (0.9606) (Figure 5).

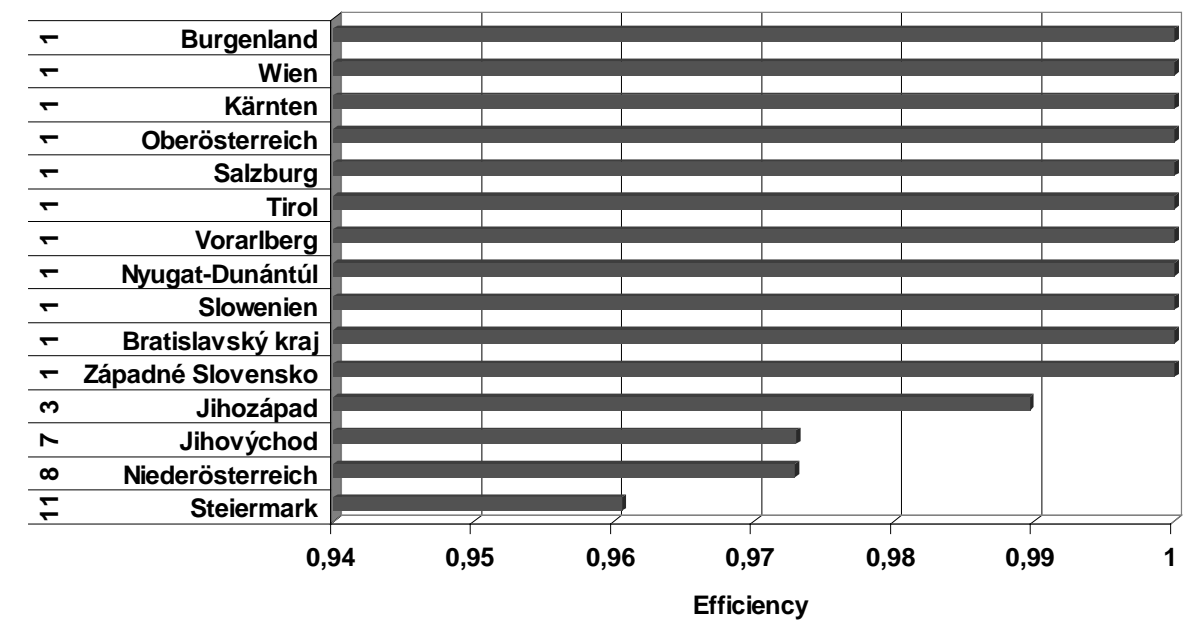

Figure 5. SOW model: position of Austrian and neighbouring regions.

Table 3 provides an overview of the individual results for the three different modelling approaches chosen. 
Table 3. Comparison of the results

\begin{tabular}{l|c|c|c}
\hline & BEOW & EEOW & SOW \\
\hline Burgenland & 59 & 49 & 1 \\
Niederösterreich & 50 & 30 & 8 \\
Steiermark & 40 & 35 & 11 \\
Kärnten & 35 & 52 & 1 \\
Wien & 28 & 2 & 1 \\
Oberösterreich & 19 & 18 & 1 \\
Vorarlberg & 6 & 10 & 1 \\
Tirol & 5 & 8 & 1 \\
Salzburg & 3 & 9 & 1 \\
Nyugat-Dunántúl & 32 & 58 & 1 \\
Slovenia & 13 & 46 & 1 \\
Jihozápad & 12 & 36 & 3 \\
Jihovýchod & 16 & 31 & 7 \\
Západné Slovensko & 45 & 22 & 1 \\
Bratislavský kraj & 11 & 1 & 1 \\
\hline
\end{tabular}

\section{Conclusions}

According to the Lisbon primacy of competitiveness, this paper aims to propose a novel and objective way to benchmark the location attractiveness of 61 European regions. This kind of benchmarking exercise does not primarily intend to provide background information for purposes of location marketing. Its main focus is to assess the capability of a region to prevail in the international competition for (foreign) direct investment in accordance with current income and employment levels and dynamics and other aspects of regional quality. Since the data are ear-marked to distinguish between region-specific and nation-specific factors, through intersection with the associated political action fields it is also possible to attribute the identified levers to political responsibilities.

The proposed methodology turns the procedure for determining the weights for the indicators used on its head and initially only requires a consensus about the applicability of abstract fairness criteria for the competition among regions. Once a specific criterion has been accepted as fair, the results of the automated calculation cannot be rejected just because of a possibly unfavourable ranking outcome. The reason is that the individual weights are endogenously deduced through an algorithmic implementation of the fairness criteria, which had been accepted beforehand. Therefore any discretionary intervention from outside is neither feasible nor possible. Rank-engineering is thus excluded.

This approach allows identification of the indicator-specific contribution to the overall positioning of a region. Furthermore, the analysis unveils the indicators with the greatest leverage in terms of improving regional attractiveness, leading to a regional strengths-/weaknesses-profile that derives directly from the model. The information on the contribution of individual indicators to the current position of a 
region can then be employed for simulation analysis in order to identify those indicator bundles that help achieve the maximum position improvement of a region for a given degree of (structural) change. And conversely, it is also possible to assess the effectiveness of a given set of regional economic policy measures in terms of enhancing location attractiveness.

A comparison of the position of the investigated regions on the basis of the three different methods used reveals that even regions, which did not achieve the best results with the BEOW and EEOW procedures (such as Burgenland, Kärnten, and Nyugat-Dunántúl) may reach a position on the efficiency frontier for a specific combination of factors. This insight is particularly interesting against the background that the set of location factors, which are responsible for attracting foreign direct investment, varies considerably depending on firm size, branch affiliation, technology intensity, and several other factors. According to the results of the SOW model, a region may find itself in a favourable position in terms of location conditions for a highly specific profile of requirements in spite of a less favourable result in mainstream rankings. This approach reflects the phenomenon that a region albeit featuring a below-average endowment with location factors most frequently sought for, may provide a highly attractive location profile for certain niche productions.

\title{
Acknowledgements
}

Partial financial support from the Austrian National Bank (Jubiläumsfonds Grant No. 10.883) is gratefully acknowledged.

\author{
Addresses: \\ Daniela Grozea-Helmenstein \\ IHS Institute for Advanced Studies \\ Stumpergasse 56 \\ A-1060 Vienna, Austria \\ Tel.: +43159991226 \\ E-mail: grozea@ihs.ac.at \\ Christian Helmenstein \\ Economica Institute of Economic Research \\ Schottenfeldgasse 29 \\ A-1070 Vienna, Austria \\ Tel.: +436763200 401 \\ E-mail: christian.helmenstein@esce.org \\ IV Federation of Austrian Industries \\ Schwarzenbergplatz 4 \\ A-1031 Vienna, Austria \\ Tel.: +43 1711352370 \\ E-mail: c.helmenstein@iv-net.at
}


Tatjana Slavova

IHS Institute for Advanced Studies

Stumpergasse 56

A-1060 Vienna, Austria

Tel.: +4369919411566

E-mail: slavov@chello.at

\section{References}

Afonso, A., M. St. Aubyn (2005) "Cross-country efficiency of secondary education provisions: a semiparametric analysis with non-discretionary inputs". (Working Paper Series, 494.) European Central Bank.

Aizenman J. and M. Spiegel (2002) "Institutional efficiency, monitoring costs, and the investment share of FDI". University of California Santa Cruz.

Althaler, S. K. and T. Slavova (2000) "DEA problems under geometrical or probability uncertainties of sample data". (Economics Series, 89.) Vienna: Institute for Advanced Studies.

Adams, L. and P. Régibeau (1998) "Optimal trade policy in the presence of DFI and internal tax competition". Presented at the European Summer Symposium in Economic Theory.

Antras, P. and E. Helpman (2004) "Global sourcing". Journal of Political Economy 112, 3, 552-580.

Atkinson, R. D. and P. D. Gottlieb (2001) "The metropolitan new economy index: benchmarking economic transformation in the nation's metropolitan areas". Washington, D. C.: Progressive Policy Institute.

Baldwin, R. and G. Ottaviano (1997) "Multiproduct multinationals and reciprocal FDI dumping". Mimeo. Geneva: Graduate Institute of International Studies.

Barros, P. P. and L. Cabral (2000) "Competing for foreign direct investment". Review of International Economics 8, 2, 360-371.

Beyko, I. W., T. W. Bodachivsjka, and T. W. Korobko (2005) "The problems of multicriteria estimations with incomplete data with the use of the aggregated Slavova criteria". In Problems of stochastic and discrete optimization. International Ukrainian-Polish Workshop, Kaniv, 2005, 111-112.

Bhagwati, J. (1987) "VERs, Quid Pro Quo DFI and VIEs: political economy theoretic analysis". International Economic Journal 1, 1, 1-14.

De Vol, R. C. (1999) "America's high-tech economy: growth, development, and risks for metropolitan areas". Santa Monica, California: Milken Institute.

Department of Trade and Industry (DTI) (2001) Regional competitiveness indicators. London: DTI.

Dunning J. H. (1979) "Explaining changing patterns of international production: in defence of the eclectic theory". Oxford Bulletin of Economics and Statistics 41, 269-295.

Ekholm, K. (2004) "Multinational enterprises and their effect on labour markets". In Globalization and the welfare state. B. Södersten, ed. Basingstoke, Hampshire: Palgrave.

EUROSTAT (2005) "Regions: statistical Yyearbook 2005". Eurostat, the European Commission, Luxembourg: Office for Official Publications of the European Communities.

Felderer B., C. Fölzer, C. Helmenstein, I. Voicu, and C. Zulehner (1999) Standortaffinität internationaler Wachstumsunternehmen. Wien: Institut für Höhere Studien.

Greene, W. H. (1993) "The econometric approach to efficiency analysis".In The measurement of productive efficiency: techniques and applications. H. O. Fried, C. A. K. Lovell, and S. S. Schmidt, eds. New York: Oxford University Press.

Grozea-Helmenstein, D., C. Helmenstein, and T. Slavova (2005) "Benchmarking the location attractiveness of regions". (OeNB Anniversary Fund Study No. 10.883) Vienna: Institute for Advanced Studies (IHS).

Helmenstein, C. (2001) "FDI-determinierende Standortfaktoren”. In Österreichs Außenwirtschaft, 161-173. Wien: Bundesministerium für Wirtschaft und Arbeit.

Helpman, H (1984) “A simple theory of international trade with multinational corporations". Journal of Political Economy 92, 3, 451-471. 
Herrera, S., G. Pang (2005) "Efficiency of public spending in developing countries: an efficiency frontier approach". World Bank Policy Research, Working Paper 3645.

Huggins, R. (2003) "Creating a UK competitiveness index: regional and local benchmarking". Regional Studies 9, 89-96.

Huggins, R. and H. Izushi (2001) "Global benchmarking of knowledge based regional economies". Paper presented to the Annual Conference of the Regional Studies Association, Regionalizing the Knowledge Economy, November, London.

Kempkes, G., C. Pohl (2007) "The efficiency of German universities - some evidence from nonparametric and parametric models". CESifo Venice Summer Institute.

King, I., P. McAfee, and L. Welling (1993) "Industrial blackmail: dynamic tax competition and public investment". Canadian Journal of Economics 26, 590-608.

King, I. and L. Welling, (1992) "Commitment, efficiency and footloose firms". Economica (London School of Economics and Political Science) 59, 233, 63-73.

Kravis, I. B. and R. E. Lipsey (1982) "The location of overseas production and production from export by US multinational firms". Journal of International Economics 12, 3-4, 201-223.

Markusen, J. (1984) "Multinational, multi-plant economies and the gains from trade". Journal of International Economics 16, 3-4, 205-226.

Markusen, J. and A. Venables (1995) "The theory of endowments, intra-industry and multinational trade". CEPR Discussion Paper No. 1341.

Mullen, J. K. and M. Williams (2005) "Foreign direct investment and regional economic performance". Kyklos 58, 2, 265-282.

Parcero, O. J. (2004) “Inter-region competition for FDI”. CMPO Working Paper Series No. 04/100, May.

Peneder, M. (1999) "Wettbewerbsfähigkeit und Standortqualität. Eine Kritik der Länder-Ranglisten”. Wirtschaftspolitische Blätter 46, 3, 170-177.

Porter, M. and S. Stern (1999) "The new challenge to America's prosperity: findings from the innovation index". Washington, DC.: Council on Competitiveness.

Resmini, L. (2007) "The determinants of FDI in central, eastern and south-eastern Europe: lessons from the past and prospects for the future". In Foreign direct investment in Europe: a changing landscape (CEEI 2006). Klaus Liebscher, Josef Christl, Peter Mooslechner, and Doris Ritzberger-Grünwald, eds. Cheltenham, UK: Edward Elgar Publishing.

Schönert, M. (2003) Städteranking und Imagebildung - Die 20 größten deutschen Städte in Nachrichten- und Wirtschaftsmagazinen. Vol. 2. Bremen: BAW Institut für Wirtschaftsforschung.

Shatz, H. J. and A. J. Venables (2000) "The geography of international investment". The Oxford Handbook GERTLER, ch.7. Oxford, U.K.: Oxford University Press.

Todd, M. and V. Gunnarsson (2007) "Budget rigidity and expenditure efficiency in Slovenia". International Monetary Fund (IMF), Working Paper WP/07/131.

Veugelers, R. (1991) "Locational determinants and ranking of host countries: an empirical assessment". Kyklos 44, 3, 363-382.

UNCTAD (1998) World Investment Report 1998. New York and Geneva: United Nations.

Wei, Shang-Jin (2000) "Local corruption and global capital flows". Brookings Papers and Economic Activity 2, 303-353.

World Economic Forum, ed. (1999) "The global competitiveness report". World Economic Forum / New York: Oxford University Press. 